\title{
Short Communication: The potential of various indigenous Trichoderma spp. to suppress Plasmodiophora brassicae the pathogen of clubroot disease on cabbage
}

\author{
I KETUT SUADA \\ Program of Agroecotechnology, Faculty of Agriculture, Universitas Udayana. Jl. P. B. Sudirman, Denpasar 80225, Bali, Indonesia. Tel./fax.: +62- \\ 361-702801, email: ketutsuada@unud.ac.id
}

Manuscript received: 19 July 2017. Revision accepted: 6 September 2017

\begin{abstract}
Suada IK. 2017. Short Communication: The potential of various indigenous Trichoderma spp. to suppress Plasmodiophora brassicae, the pathogen of clubroot disease on cabbage. Biodiversitas 18: 1424-1429. On the island of Bali, cabbage (Brassica oleracea L.) is a vegetable that has high economic value especially for farmers who cultivate it as a cash crop. However, the clubroot disease caused by the microbial pathogen Plasmodiophora brassicae decreases its productivity. Much effort has been expended in attempts to decrease the pathogen attack by use of synthetic fungicides, however, this has not had much success; more over such pesticide applications generate environmental pollution. Therefore, biological control using Trichoderma or other organisms antagonistic to the pathogen is an attractive alternative. The purpose of this study was to find, isolate and identify Trichoderma spp. able to decrease the disease incidence and increase plant growth. Twelve indigenous Trichoderma isolates were tested on cabbage plants grown in polybags containing local soil media culture treated with the Trichoderma inocula at a concentration of $1.5 \times 10^{6} \mathrm{CFU}$ per polybag. The results showed that three Trichoderma isolates, i.e. T. hamatum-1, T. harzianum-1, and T. harzianum-2, were able to decrease the clubroot disease and increase cabbage growth as well.
\end{abstract}

Keywords: Biocontrol, cabbage, clubroot, Trichoderma

\section{INTRODUCTION}

Cabbage (Brassica oleracea L.) is a popular vegetable beneficial to health because it contains vitamins A, B1, C, and minerals, and is therefore in high demand on the island of Bali, Indonesia. However, the production of local cabbages in Bali has been in steady decline since 2010: in that year, the production of cabbages in Bali amounted to 47,077 tons, in 2011 it was 42,926 tons, in 2012 40,167 tons, but in 2013 it only reached 35,781 tons (Central Bureau of Statistics of Bali Province 2014). This decline in production was closely related to the observed high incidence of clubroot disease caused by the microbial pathogen Plasmodiophora brassicae Woronin, responsible not only for the disease in cabbage plants, but also for attacking other members of the family Brassicaceae.

According to local farmers, clubroot disease is an important issue in every crop season and occurs in almost every cabbage-growing area in Bali. Disease control using pesticides is often not effective against soil borne pathogens such as the clubroot pathogen. Moreover, excessive use of fungicides is polluting the environment. As a result, public attention has been increasingly drawn to environmental safety concerns, leading to limitations being placed on pesticide application.

A potential alternative to the use of chemical pesticides in the control of clubroot disease of cabbages is an environmentally friendly control system based on biological agents such as fungi or bacteria antagonistic to the clubroot pathogen. One such antagonist with potential to be used as a biocontrol agent is the fungal genus Trichoderma Persoon. Besides being able to protect the cabbage against clubroot-disease caused by Plasmodiophora brassicae, Trichoderma also can control various other diseases caused by fungal pathogens (Cheah and Page 1997; Navi and Bandyopadhyay 2002). Fungal pathogens that have been reported as being controlled to some degree by Trichoderma spp. Include Pythium, Phytophthora, Fusarium, Rhizoctonia, Sclerotium, and Verticillium (Nederhoff 2001; Agrios 2005; Arya and Perello 2010). The use of introduced Trichoderma spp. has been reported to reduce pathogen attacks by about $25 \%$, while the use of fermented livestock manure combined with Trichoderma spp. in cabbage reduced pathogen attack by $51 \%$ (Legowo 2010). In addition, to acting as antagonists against pathogens, Trichoderma can also act as a plant growth promoter, because the interaction between Trichoderma and plants has been reported to stimulate formation of plant growth hormones(Harman et al. 1991).

In the research literature, there are documented cases of obstacles encountered in testing for the effectiveness of various antagonist agents against pathogens. The major factors that influence the effectiveness of antagonist agents are environmental extremes include temperature fluctuations, ultraviolet light, $\mathrm{pH}$, availability of water and nutrients, as well as competition from indigenous microflora (Agrios 2005; Renwick and Poole 1989; Zhu et al. 2016). As a result, there are problems in the adaptation of some introduced biological agents to the environment of their application site. 
Microbial control agents introduced to help protect crops against pathogens that cause root disease must adapt to the environment of the application site and to the rhizosphere of the crop plants if they are to function properly as antagonist agents. Moreover, an antagonist agent is usually propagated in an artificial media so becoming accustomed to the optimum conditions of that medium. This tends to reduce its completive abilities when introduced to the open field conditions of a growing crop. Furthermore, the genetics of the pathogenic microbe and also of the antagonistic agent generally has a capacity to change quickly, and so the effectiveness of the antagonist against the pathogen can change rapidly as well. At the site of introduction, biological agents can be inhibited by the new environmental conditions resulting in lower than expected effectiveness under field conditions.

Weller (1988), in his wheat research, has clearly revealed that although introduced microbes may dominate in a new location for the few first weeks, by the end of the growing season they can decline in vigor and their population drop to less than $2 \%$ of the original population. Even genetically modified agents can experience the same thing, such that their population shrinks drastically and they no longer remain effective as biological agents.

The research reported in this paper was undertaken to obtain and identify local Trichoderma spp. isolates able to be used as biocontrol agents in cabbage crops grown in Bali. The purpose of the study was to culture these Trichoderma isolates and apply them at populations suitable for controlling clubroot disease and enhancing growth of cabbage plants under local conditions.

\section{MATERIALS AND METHODS}

\section{Soil sampling}

Soils were sampled in farmers' vegetable gardens, from the rhizosphere of various type of cabbages infected by clubroot disease in the area of Bedugul, Tabanan, Bali. Each sample of $200 \mathrm{~g}$ was placed in a plastic bag. The samples were packaged in a box that had been filled with ice to protect them from sun damage and overheating, and then transported to the Biotechnology Laboratory of the Faculty of Agriculture, University of Udayana, Denpasar, Bali, Indonesia.

\section{Isolation and identification of Trichoderma spp.}

In the Biotechnology Laboratory, isolation of Trichoderma spp. from the soil samples was carried out by culturing on PDA (Potato Dextrose Agar) media containing100 ppm Streptomycin as an antibiotic for bacteria.

Colonies of growing fungi were subcultured and then identified by observation under a microscope; matching the fruiting bodies of the fungal isolates to reference images documented in Alexopoulos and Mims (1979), Barnett and Hunter (1972), CMI (1988), Webster and Weber (2007), Domsch et al. (1980), and Watanabe (2002), and also by using the taxonomic key of Samuels et al. (2006). The right
Trichoderma inocula were subcultured using a single spore isolation technique. A serial dilution method was used to obtain dilutions of $10^{-1}-10^{-7}$. One milliliter of suspension of dilution rate of $10^{-3}-10^{-7}$ was cultured in sterile PDA medium containing $100 \mathrm{ppm}$ Streptomycin to prevent bacterial contaminants growth.

\section{Design of the experiment to test Trichoderma isolates on cabbage plants}

The experiment to test isolates was performed in a greenhouse of the Faculty of Agriculture. Polybags (diameter $12.5 \mathrm{~cm} \times$ height $20 \mathrm{~cm}$ ) received $2.5 \mathrm{~kg}$ of a mixed medium (local soil:compost, at a ratio of $3: 1$ ). Each polybag was planted with one three-week-old cabbage seedlings. For every isolate to be tested, 9 polybags were assigned. Altogether, twelve Trichoderma isolates were tested in the experiment, and their impacts on cabbage plant growth was compared with a control treatment that consisted of cabbage plants with no Trichoderma application. Thus, the experiment consisted of a total of thirteen treatments with three replications per treatment (each with three sample plants per polybag), arranged in a completely randomized design. Each of the twelve Trichoderma treatments received $1.5 \times 10^{6}$ spores of the particular assigned Trichoderma isolate in $200 \mathrm{ml}$ water, applied as a drench to the soil around the base of the cabbage plants.

\section{Maintenance of the cabbage plants}

The polybags were fertilized twice; i.e. at one and three weeks after planting. Fertilizer was given at a dose of 1.3 g/plant ZA (Zwavelzure Ammoniak, 20.8\% Nitrogen), 1.8 g/plants TSP (Triple Super Phosphate, 45\% $\mathrm{P}_{2} \mathrm{O}_{5}$ ), and 0,7 $\mathrm{g} /$ plant $\mathrm{KCl}$ (Potassium chloride, $60 \% \mathrm{~K}_{2} \mathrm{O}$ ). Plants were watered until the soil moisture was stable at field capacity. Plants of all treatments were sprayed with foliar fertilizer DI Grow (liquid organic fertilizer contained macro, micro elements, and growth regulator) at a concentration of 2 $\mathrm{cc} / \mathrm{L}$ at a dose equivalent to $400 \mathrm{~L} / \mathrm{ha}$.

\section{Observation variables}

The observed variables were: plant height, measured from the ground to the tip of the leaf held erect; total number of leaves; number of galls (i.e. number of large and/or small galls per plant), counted after the plants were upended at the end of the experiment; percentage of plants attacked (\%), calculated from the number of plants that had a gall after the plant was upended; leaf chlorophyll content, measured by a SPAD Chlorophyll Meter; leaf area, measured by a Leaf Area Meter. All these variables were observed at7 weeks after planting, i.e. prior to the plants forming cabbage hearts.

\section{Data analysis}

Data were analyzed by ANOVA appropriate to a completely randomized design (CRD), followed by a Duncan's Multiple Range Test at a 1\% and 5\% significance level, to differentiate the effects of isolates. 


\section{RESULTS AND DISCUSSION}

\section{Antagonistic Trichoderma spp.}

From the soil obtained in the rhizosphere of various plants sampled at the study site, twelve specimens of Trichoderma spp. were isolated in the laboratory. The characteristics of the twelve isolates are described in Table 1 and Figure 1.

Based on observation by microscope, the isolates could be assigned to four different groups with the characteristics shown in Table 2.

As listed in Table 2, the twelve isolates were identified as belonging to four Trichoderma spp., namely $T$. hamantum, T. harzianum, T. polysporum, and T. koningii. Generally, the Trichoderma fungal colonies were found to be white-green in color after three days growth on PDA but they gradually turned bluish toward the seventh days. Within 6 to 7 days, colonies had reached a diameter of 9 $\mathrm{cm}$, which resulted in them reaching the outer edge of the media in the petri dishes.

\section{Performance of the cabbage plants in the experiment evaluating the Trichoderma isolates}

Observations carried out on the cabbage plants evaluated for the effects of the Trichoderma isolates comprised measurements of plant height, leaf number, leaf area, and leaf chlorophyll at seven weeks after planting, just before the plants began to form cabbage hearts.

Plant height and total leaf number did not show a significant difference between the isolate treatments (based on Duncan Multiple Range test at 5\% level). However, there was a significant difference between isolate treatments in leaf area and leaf chlorophyll. The largest leaf area was found in isolate treatment Tri-1 (T. hamatum-1) with a total leaf area of $95.24 \mathrm{~cm}^{2}$ leaf area. Its chlorophyll estimate was also the highest, namely 3596.26 SPAD units of chlorophyll (see Wood et al. 1992). These results indicated a beneficial response of the cabbage plant to the fungus $T$. hamatum-1, an interaction that promoted plant growth (Table 3). According to Suwahyono and Wahyudi (2004), Trichoderma can act not only as a biological control agent, but the fungus can also act as a driver of growth, improving plant performance: Trichoderma can stimulate the formation of growth hormones that enhance plant growth. Trichoderma species that have been reported to act in this way are T. harzianum, T. polysporum, and T. viridae. In this current study, the most probable isolate with the described property was T. hamatum-1. Compared to other isolates, T. hamatum in this study was better in its effects on cabbage plant performance than T. harzianum and T. polysporum.

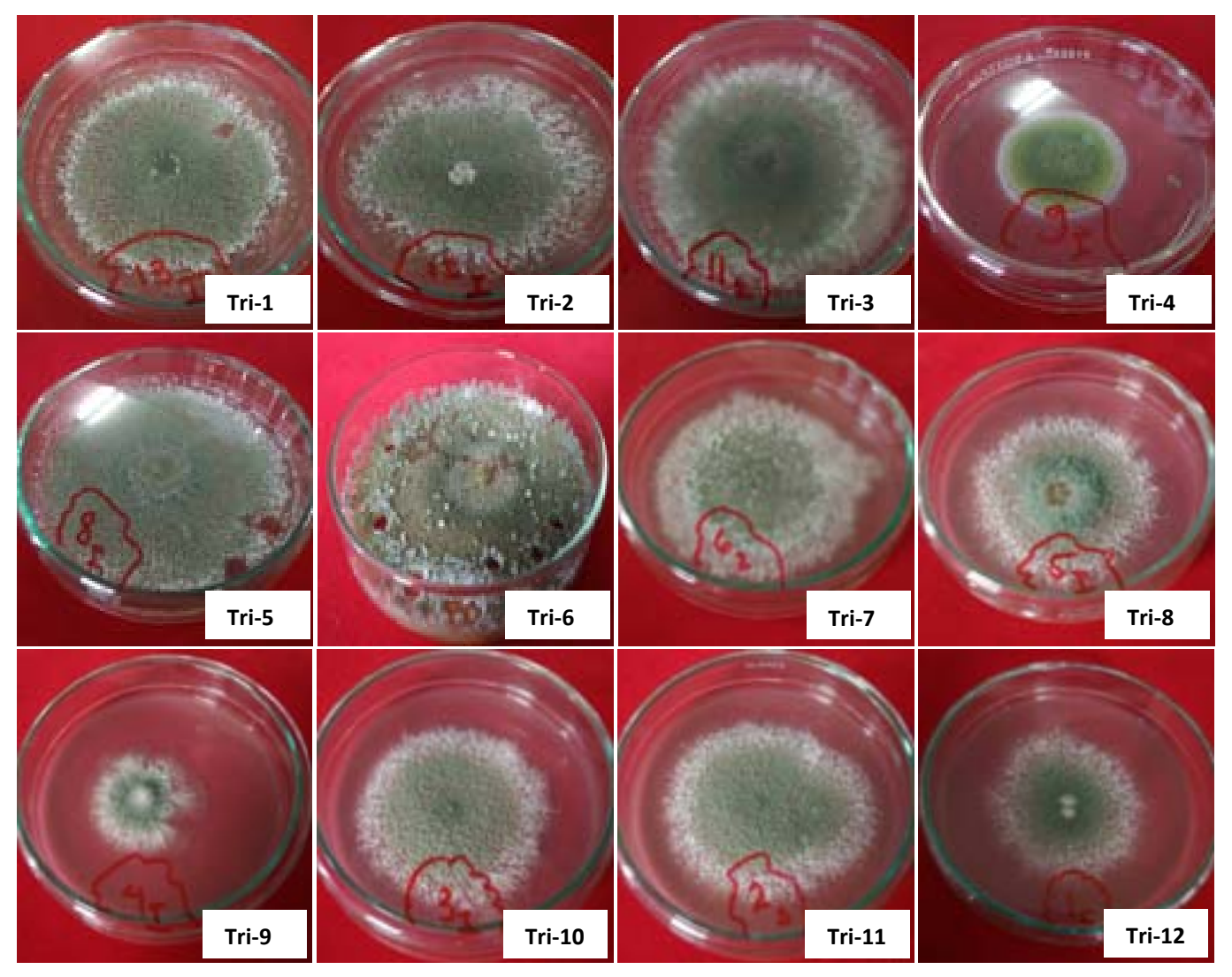

Figure 1. Various types of Trichoderma spp. colonies isolated from the rhizosphere of healthy plants in farmers' fields where clubroot disease was prevalent 
Table 1. Characteristics of the colony development of twelve Trichoderma spp. isolates cultured on PDA medium

\begin{tabular}{|c|c|c|c|c|c|c|c|c|}
\hline \multirow[b]{2}{*}{ Isolate } & \multicolumn{7}{|c|}{ Color at colony age (day 1 to 7 ) } & \multirow{2}{*}{$\begin{array}{c}\text { Colony } \\
\text { form }\end{array}$} \\
\hline & 1 & 2 & 3 & 4 & 5 & 6 & 7 & \\
\hline Tri-1 & White & Greenish white & Greenish white & Greenish white old & Light green & Green & Dark green & Round \\
\hline Tri-2 & White & Greenish white & Light green & Greenish white old & Light green & Green & Green & Round \\
\hline Tri-3 & White & White & Greenish white & Greenish white old & Light green & Green & Dark green & Round \\
\hline Tri-4 & White & White & Green & Dark green & Light green & Dark green & Dark green & Round \\
\hline Tri-5 & White & Greenish white & Greenish white & Greenish white old & Light green & Green & Dark green & Round \\
\hline Tri-6 & White & Greenish white & Greenish white & Greenish white old & Light green & Green & Dark green & Round \\
\hline Tri-7 & White & Greenish white & Light green & Greenish white old & Light green & Green & Dark green & Round \\
\hline Tri-8 & White & Greenish white & Light green & Greenish white old & Light green & Green & Dark green & Round \\
\hline Tri-9 & White & Greenish white & Light green & Greenish white old & Light green & Green & Dark green & Round \\
\hline Tri-10 & White & White & Greenish white & Greenish white old & Light green & Green & Dark green & Round \\
\hline Tri-11 & White & Greenish white & Greenish white & Greenish white old & Light green & Green & Dark green & Round \\
\hline Tri-12 & White & Greenish white & Light green & Greenish white old & Light green & Green & Dark green & Round \\
\hline
\end{tabular}

Note: Tri=Trichoderma spp. Numbers that follow Tri is an identifying numbers for isolates obtained from various healthy plants in farmers' fields where clubroot disease was endemic

Table 2. Characteristics of Trichoderma spp. isolated from the rhizosphere of various healthy plants

\begin{tabular}{lllll}
\hline \multirow{2}{*}{ Isolate } & \multicolumn{3}{c}{ Microscopic characteristics } & Conidia \\
\cline { 2 - 5 } & Conidiophore & Phialides & Oval & T. hamantum-1 \\
\hline Tri-1 & Erect, branched & Short, thick & Oval & T. harzianum-1 \\
Tri-2 & Erect, branched & Short, thick & Oval & T. polysporum-1 \\
Tri-3 & Branched & Long, very thick & Oval & T. harzianum-2 \\
Tri-4 & Erect, branched & Short, thicker & Oval & T. harzianum-3 \\
Tri-5 & Erect, branched & Short, thick & Oval & T. hamantum-2 \\
Tri-6 & Erect, branched & Short, thick & Oval & T. hamantum-3 \\
Tri-7 & Erect, branched & Short, thick & Oval and round & T. koningii-1 \\
Tri-8 & Erect, branched & Small, taper & Oval & T. hamantum-4 \\
Tri-9 & Erect, branched & Short, thick & Oval & T. polysporum-2 \\
Tri-10 & Branched & Long, very thick & Oval & T. polysporum-3 \\
Tri-11 & Branched & Long, very thick & Oval and round & T. koningii-2 \\
Tri-12 & Erect, branched & Small, taper &
\end{tabular}

Note: Tri=Trichoderma spp. Numbers that follow Tri are identifying numbers for the isolates obtained from various healthy plants in the field areas where clubroot disease was prevalent.

Table 3. Effect of isolates of Trichoderma spp. on several cabbage plant variables at seven weeks after planting

\begin{tabular}{lcccc}
\hline \multirow{2}{*}{ Treatment } & \multicolumn{4}{c}{ Variables of plant performance } \\
\cline { 2 - 5 } & Height $\mathbf{( c m )}$ & Total leaf number & Leaf area (cm $\left.\mathbf{c m}^{2}\right)$ & Leaf chlorophyll (SPAD) \\
\hline Control (no Tri) & $14.45 \pm 3.23 \mathrm{a}$ & $9.33 \pm 0.89 \mathrm{a}$ & $28.43 \pm 43 \mathrm{~b}$ & $1007.84 \pm 2.56 \mathrm{~d}$ \\
Tri-1 & $17.79 \pm 2.44 \mathrm{a}$ & $11.00 \pm 5.14 \mathrm{a}$ & $95.24 \pm 6.75 \mathrm{a}$ & $3596.26 \pm 3.66 \mathrm{a}$ \\
Tri-2 & $16.45 \pm 4.35 \mathrm{a}$ & $10.00 \pm 2.11 \mathrm{a}$ & $64.36 \pm 3.76 \mathrm{ab}$ & $2413.50 \pm 7.54 \mathrm{~b}$ \\
Tri-3 & $14.88 \pm 1.57 \mathrm{a}$ & $9.66 \pm 3.55 \mathrm{a}$ & $43.42 \pm 5.22 \mathrm{~b}$ & $1577.44 \pm 6.77 \mathrm{c}$ \\
Tri-4 & $16.08 \pm 2.65 \mathrm{a}$ & $9.66 \pm 2.45 \mathrm{a}$ & $64.01 \pm 6.32 \mathrm{ab}$ & $2349.16 \pm 12.69 \mathrm{~b}$ \\
Tri-5 & $14.56 \pm 3.56 \mathrm{a}$ & $9.33 \pm 1.79 \mathrm{a}$ & $31.66 \pm 4.33 \mathrm{~b}$ & $1122.34 \pm 11.54 \mathrm{~d}$ \\
Tri-6 & $14.45 \pm 3.77 \mathrm{a}$ & $10.00 \pm 2.19 \mathrm{a}$ & $35.48 \pm 3.22 \mathrm{~b}$ & $1321.98 \pm 32.56 \mathrm{~d}$ \\
Tri-7 & $14.54 \pm 1.33 \mathrm{a}$ & $9.33 \pm 2.17 \mathrm{a}$ & $49.09 \pm 2.11 \mathrm{ab}$ & $1819.27 \pm 18.23 \mathrm{c}$ \\
Tri-8 & $17.06 \pm 2.35 \mathrm{a}$ & $10.33 \pm 1.35 \mathrm{a}$ & $58.40 \pm 3.24 \mathrm{ab}$ & $2219.93 \pm 10.23 \mathrm{~b}$ \\
Tri-9 & $16.54 \pm 2.33 \mathrm{a}$ & $9.66 \pm 3.44 \mathrm{a}$ & $61.45 \pm 3.44 \mathrm{ab}$ & $2284.09 \pm 9.34 \mathrm{~b}$ \\
Tri-10 & $15.54 \pm 1.14 \mathrm{a}$ & $10.00 \pm 1.35 \mathrm{a}$ & $62.25 \pm 4.68 \mathrm{ab}$ & $2311.34 \pm 16.88 \mathrm{~b}$ \\
Tri-11 & $15.63 \pm 4.12 \mathrm{a}$ & $9.66 \pm 2.33 \mathrm{a}$ & $41.38 \pm 3.56 \mathrm{~b}$ & $1596.02 \pm 24.15 \mathrm{c}$ \\
Tri-12 & $14.94 \pm 3.66 \mathrm{a}$ & $10.00 \pm 2.56 \mathrm{a}$ & $26.09 \pm 2.77 \mathrm{~b}$ & $965.33 \pm 13.24 \mathrm{~d}$ \\
\hline
\end{tabular}

Note: Tri=Trichoderma spp. Numbers that follow Tri are numbers identifying particular isolates obtained from various healthy plants in a field area where clubroot disease was prevalent. Data are expressed as means \pm SDs. Values followed by the same letters in the same column do not differ significantly at 5\% probability level according to Duncan Multiple Range test 

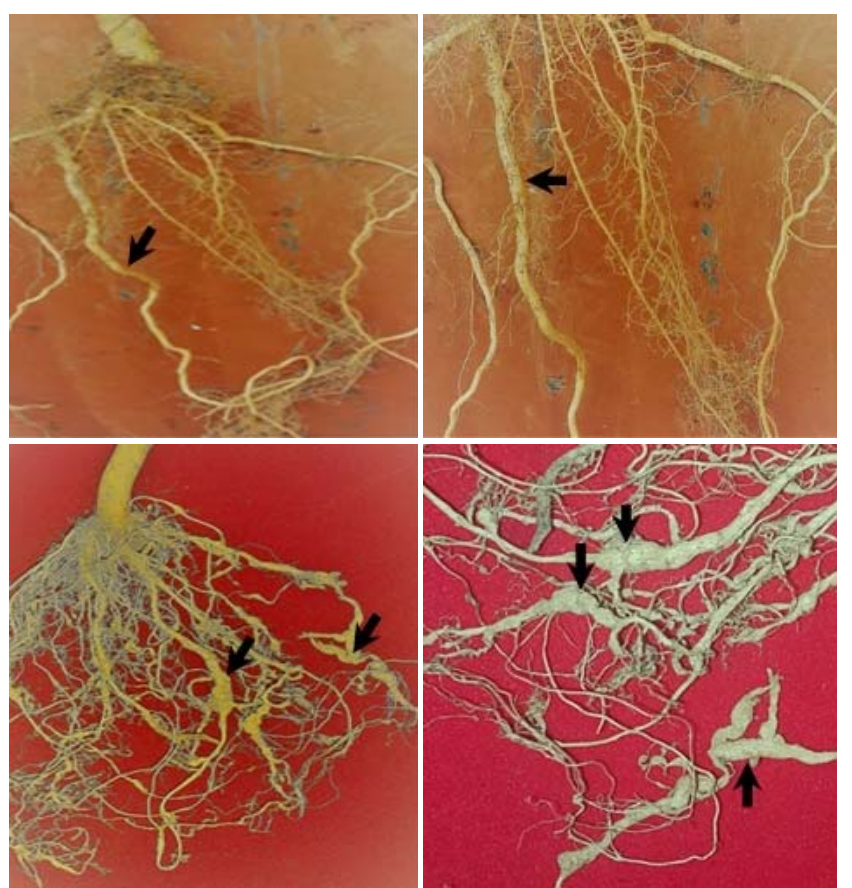

Figure 2. The appearance of the plant roots at seven weeks after planting. Asymptomatic roots (above) and galled roots (below)

\section{Incidence of clubroot on cabbage plants}

The effect of the Trichoderma isolates on incidence of clubroot in the cabbage was rated based on two variables i.e. the number of clubroot galls and the percentage of infected plants (Figure 2). It proved not possible to effectively categorize all galls according to size into large or small, and so all galls irrespective of size were counted as single galls. The percentage of infected plants was obtained by dividing the number of plants with gall(s) by the total number of plants observed, expressed as a percentage.

Tri-1, that is T. hamatum-1, completely suppressed the formation of galls, so that the incidence of clubroot in this treatment was zero, this suggests that Tri-1 may be antagonistic to the growth of the pathogen ( $P$. brassicae). Furthermore, Tri-2 (T. harzianum-1) also demonstrated the same total suppression of gall formation, while Tri-4, Tri- 8 and Tri-9 showed a relatively low disease incidence $(11.11 \%)$ (Table 4). The isolates Tri-1 and Tri-2 were effective in disease-suppression and also appeared to promote the health of the cabbage plants as indicated by high total chlorophyll estimates of 3596.26 and 2413.50 SPAD respectively. That means that the two Trichoderma isolates may act not only as biological control agents, but may also enhance plant growth. Plants with a high leaf chlorophyll content would be expected to have enhanced photosynthesis and hence enhanced ability to form carbohydrates. Many studies have reported that increased chlorophyll concentrations in plant leaves, achieved by improved nutrition, are correlated with higher yields in agricultural and horticultural crops (Wood et al. 1992; Kararurt et al. 2009; Fan et al. 2014).
Table 4. Incidence of clubroot disease observed in cabbage plants treated with different Trichoderma spp. isolates

\begin{tabular}{lcc}
\hline & \multicolumn{2}{c}{ Observation variables } \\
\cline { 2 - 3 } Treatment & $\begin{array}{c}\text { Gall number } \\
\text { (pieces/plant) }\end{array}$ & $\begin{array}{c}\text { Disease incidence } \\
\text { (\%) }\end{array}$ \\
\hline Control (no Tri) & $8.94 \pm 3.03 \mathrm{a}$ & $100.00 \mathrm{a}$ \\
Tri-1 & $0.00 \mathrm{~d}$ & $0.00 \mathrm{~d}$ \\
Tri-2 & $0.00 \mathrm{~d}$ & $0.00 \mathrm{~d}$ \\
Tri-3 & $8.22 \pm 2.00 \mathrm{a}$ & $100.00 \mathrm{a}$ \\
Tri-4 & $2.33 \pm 0.21 \mathrm{c}$ & $11.11 \pm 0.25 \mathrm{c}$ \\
Tri-5 & $7.89 \pm 2.13 \mathrm{a}$ & $55.55 \pm 05.00 \mathrm{~b}$ \\
Tri-6 & $7.45 \pm 2.22 \mathrm{a}$ & $55.55 \pm 1.00 \mathrm{~b}$ \\
Tri-7 & $7.35 \pm 3.02 \mathrm{a}$ & $33.33 \pm 3.95 \mathrm{~b}$ \\
Tri-8 & $4.33 \pm 2.41 \mathrm{~b}$ & $11.11 \pm 2.13 \mathrm{c}$ \\
Tri-9 & $2.78 \pm 0.02 \mathrm{c}$ & $11.11 \pm 2.16 \mathrm{c}$ \\
Tri-10 & $7.35 \pm 1.80 \mathrm{a}$ & $55.55 \pm 05.00 \mathrm{~b}$ \\
Tri-11 & $7.78 \pm 2.02 \mathrm{a}$ & $44.44 \pm 3.55 \mathrm{~b}$ \\
\hline
\end{tabular}

Note: Tri=Trichoderma spp. Numbers that follow Tri are numbers identifying particular isolates obtained from various healthy plant in a field area where clubroot disease was prevalent. Data are means \pm SDs. Values followed by the same letters within the same column are not significantly different at a 5\% level of significance, based on Duncan Multiple Range test. Percentage data were analyzed after arc-sin $\sqrt{(}(x+1 / 2)$ conversion.

It is possible that a beneficial Trichoderma-crop association results in growth enhancement of the plants via promotion of photosynthesis as indicated by the high chlorophyll content and leaf area observed in Tri-1 and Tr-2 treatments. A conclusion that follows from this research is that Trichoderma isolates capable of suppressing clubroot disease in cabbage plants also improved some parameters of cabbage plant growth. The best isolates were Trichoderma hamatum-1, followed by Trichoderma harzianum-1, and Trichoderma harzianum- 2 . Further research is needed to determine the most effective formulations that can be applied in the field.

\section{ACKNOWLEDGEMENTS}

The author wishes to thank the Rector of Udayana University, Bali, Indonesia for financial support that enabled the research to proceed smoothly. The author also expresses appreciation to the Faculty of Agriculture of Udayana University for its laboratory support. Special thanks are addressed to all my students for diligent data collection that enabled this research to be completed on time.

\section{REFERENCES}

Agrios GN. 2005. Plant Pathology. 5th ed. Burlington, California, Elsevier Academic Press, London.

Alexopoulos CJ, Mims CW. 1979. Introductory Mycology. 3rd ed. John Wiley \& Sons, New York.

Arya A, Perello AE. 2010. Management of Fungal Plant Pathogens. CAB International, London. 
Central Bureau of Statistics of Bali Province. 2014. Production of Vegetables by Regency/City in Bali. Central Bureau of Statistics of Bali Province, Denpasar. [Indonesian]

Barnett HL, Hunter BB. 1972. Illustrated Genera of Imperfect Fungi. $4^{\text {th }}$ ed. APS Press, Minnesota.

Cheah LH, Page BBC. 1997. Trichoderma spp. for potential biocontrol of clubroot of vegetable brassicas. Proceedings $50^{\text {th }}$ N.Z. Plant Protection Conference 1997, New Zealand Plant Protection Society, New Zealand.

CMI. 1988. Description of Pathogenic Fungi and Bacteria. Commonwealth Mycology Institute, England.

Domsch KH, Gams W, Anderson TH. 1980. Compendium of Soil Fungi. Volume 1. Academic Press, London.

Fan H, Wang X, Sun X, Li Y, Sun X, Zheng C. 2014. Effect of humic acid derived from sediments on growth, photosynthesis and chloroplast ultrastructure in Chrysanthemum. Scienta Horticulturae 177: 118-123.

Harman GE, Jin X, Stasz TE, Peruzzotti G, Leopold AC, Taylor AG. 1991. Production of conidial biomass of Trichoderma harzianum for biological control. Biol Control 1: 23-28.

Karakurt Y, Unlu H, Padem H. 2009. The influence of foliar and soil fertilization of humic acid on yield and quality of pepper. Acta Agric Scand Sect B 59: 233-237.

Legowo DA. 2010. Effect of Organic Material and Antagonistic Fungus Trichoderma spp. against Club Root Disease (Plasmodiophora brassicae Worr.) on Cabbage Plants [Dissertation]. Postgraduate Program, Brawijaya University, Malang. [Indonesian].
Navi SS, Bandyopadhyay R. 2002. Biological control of fungal plant pathogens. In: Waller JM, Lenne JM, Waller SJ (eds.). Plant Pathologist's Pocketbook. 3rd ed. CAB International, Wallingford.

Nederhoff E. 2001. Biological control of root diseases-especially with Trichoderma. Grower 56 (5): 24-25.

Renwick A, Poole N. 1989. The environmental challenge to biological control of plant pathogens. In: Whipps JM, Lumsden RD (eds.). Biotechnology of Fungi for Improving Plant Growth. Cambridge University Press, New York.

Samuels GJ, Dodd SL, Lu BS, Petrini O, Schroers HJ, Druzhinina IS. 2006. The Trichoderma koningii aggregate species. Stud Mycol 56: 67-133.

Suwahyono U, Wahyudi P. 2004. Use of Bio-Fungicides on Plantation Enterprises. BPPT, Tangerang Selatan. [Indonesian]

Watanabe T. 2002. Pictorial Atlas of Soil and Seed Fungi Morphologies of Cultured Fungi and Key to Species. CRC Press, U.S.A

Webster J, Weber R. 2007. Introduction to Fungi. 3rd ed. Cambridge University Press, Cambridge.

Weller DM. 1988. Biological control of soilborne pathogens in the rhizosphere with bacteria. Ann Rev Phytopathol 26: 379-407.

Wood CW, Reeves DW, Duffield RR, Edmisten KL. 1992. Field chlorophyll measurements for corn nitrogen status. J Plant Nutr 15: 487-500.

Zhu Q, Riley WJ, Tang J, Koven CD. 2016. Multiple soil nutrient competition between plants, microbes, and mineral surfaces: model development, parameterization, and example applications in several tropical forests. Biogeosciences 13: 341-363. 